\title{
Technology, R \& D and IPO Underpricing: The Moderator Effect of Venture Capital
}

\author{
Anqi Wang \\ Jinan University, Guangzhou, China \\ Email: wang-angel@foxmail.com
}

How to cite this paper: Wang, A.Q. (2018) Technology, R \& D and IPO Underpricing. The Moderator Effect of Venture Capital. Journal of Service Science and Management, 11, 631-649.

https://doi.org/10.4236/jssm.2018.116043

Received: November 26, 2018

Accepted: December 16, 2018

Published: December 20, 2018

Copyright (C) 2018 by author and Scientific Research Publishing Inc. This work is licensed under the Creative Commons Attribution International License (CC BY 4.0).

http://creativecommons.org/licenses/by/4.0/

\begin{abstract}
This paper draws up on the companies that completed IPO in GEM to investigate the influence of R \& D and technology on IPO underpricing, and venture capital (VC)'s moderator effect on this influence. We find that information asymmetry causes high-R \& D and high-tech IPOs to become underpriced. VC can play the certification role to mitigate the positive correlation between technology and IPO underpricing, while VC cannot serve as a supervisor and therefore strengthen the positive correlation between $\mathrm{R} \& \mathrm{D}$ and IPO underpricing. More importantly, IPO underpricing decreases with the interaction between $\mathrm{R} \& \mathrm{D}$ expenditure and technology. Technology requirement reduces the underpricing of high-R \& D IPOs. Accordingly, R \& D spending reduces the underpricing of high-tech IPOs. Our result is more significant for the companies with VC background.
\end{abstract}

\section{Keywords}

IPO Underpricing, Venture Capital, Technology, R \& D, Moderator Effect

\section{Introduction}

The phenomenon of IPO underpricing is widespread in the stock markets of various countries, and the problem of high IPO underpricing in China is particularly prominent. Under the background of promoting the market-oriented reform of stock pricing, academics and practitioners have always maintained a high degree of attention to this issue. The existing IPO underpricing research can be divided into two major factions: Information asymmetry and behavioral finance. The theory of information asymmetry is recognized by most people, and the classical hypothesis such as certification supervision, information transmission, and market power are born. In the past, the empirical research started from the factors of the issue scale, the establishment period, the underwriter reputa- 
tion and the support of venture capital, which all found that the information asymmetry is the basis of the IPO underpricing; in the long run, technological innovation is also an important factor in determining corporate value, but research from this perspective is scarce. The report of the 19th National Congress of the Communist Party of China proposed to firmly implement the innovation-driven development strategy and accelerate the construction of an innovative country. Today, the contribution of scientific and technological progress to China's economic growth has reached 57.5\%. It can be foreseen that the high-tech industry has ushered in an unprecedented development opportunity, and enterprises must pay more attention to $\mathrm{R} \& \mathrm{D}$ investment in order to gain competitive advantage. Although high-tech positioning and $\mathrm{R} \& \mathrm{D}$ investment can increase the future value of a company, its high-risk characteristics may also cause information asymmetry, which in turn affects corporate valuation.

In recent years, domestic and foreign scholars are keen to study the impact of venture capital on IPO underpricing. One of the characteristics of venture capital is to invest in high-risk and high-yield enterprises, and will actively participate in company's operation and management after investment, including the process from $\mathrm{R} \& \mathrm{D}$ investment to output. In view of the relationship between high-tech, R \& D investment and venture capital, this paper attempts to test and analyze the following three problems: First, high-tech enterprises have more risky investment in the early stage, and the future cash flow is uncertain; The $\mathrm{R}$ \& $\mathrm{D}$ process is not transparent enough, and the information reflected in the $\mathrm{R} \&$ $\mathrm{D}$ expenditure data on the financial statements is limited. Will these factors that cause information asymmetry increase the degree of IPO underpricing? Second, venture capital, as a professional investment institution, has professional ability in screening investment projects, estimating development prospects, and participating in business management. Can it play a positive regulatory role in the relationship of in R \& D expenditure, high-tech and IPO underpricing? Can it reduce information asymmetry, and thus reduce the IPO underpricing rate? Third, compared with general enterprises, high-tech enterprises have higher sensitivity to technological innovation, and R \& D investment has a crucial impact on their long-term development. Therefore, will high-tech enterprises with high $\mathrm{R} \& \mathrm{D}$ investment attract the attention of professional investors, ease the information asymmetry between the two parties, and then show a lower IPO underpricing rate? In response to these problems, this paper conducted an empirical test on 349 companies in China's GEM market from October 2009 to October 2012. The reasons for choosing the GEM market are: First, the IPO underpricing phenomenon is more typical in the GEM market. Second, most companies listed on the GEM are technology-based start-ups, which focus on R \& D investment, and most of them have venture capital background. All of the above features are suitable for the study.

The empirical results of this paper show that high-tech enterprises have higher IPO underpricing rates, and the involvement of venture capital can reduce the degree of information asymmetry, thus weakening the positive correlation be- 
tween high-tech background and IPO underpricing rate; the more the R \& D investment intensity, the higher the IPO underpricing, venture capital not only fails to play a role in reducing the information asymmetry, but also strengthens the positive correlation between the $\mathrm{R} \& \mathrm{D}$ investment intensity and the IPO underpricing rate; the demand for high technology will reduce information asymmetry of R \& D. similarly, R \& D investment will also alleviate the uncertainty associated with high technology, in other words, high-tech enterprises with high R \& D investment show a lower IPO underpricing rate. The paper also uses the residual centralization method to solve the multi-collinearity problem that may exist between the independent variable and the intersection term, and finds that the empirical conclusion is still stable.

Based on China's market environment, this paper studies the impact of high-tech background and R \& D investment intensity on IPO underpricing rate from the perspective of venture capital for the first time. It can help market participants and regulators understand the causes of IPO underpricing in multiple dimensions. It also helps start-ups recognize the impact of technological innovation and $\mathrm{R} \& \mathrm{D}$ investment on corporate value. In addition, the study found that China's venture capital did not fully play the role of certification supervision, and there is a tendency to speculate. The above results are an effective complement to the IPO underpricing and venture capital literature.

The article is organized as follows: The second part reviews the relevant literature and puts forward the research hypothesis based on the actual situation in China; the third part constructs the measurement model and introduces the sample data; the fourth part reports and analyzes the empirical results, including the robustness test; the fifth part is the main conclusion.

\section{Literature Review and Hypotheses Development}

In the classic research results of IPO underpricing, most scholars analyze the problem through information asymmetry between issuers, underwriters and investors. As Beatty and Ritter (1986) suggest, there is often information asymmetry between issuers and underwriters, and underwriters in a dominant position tend to be underpricing issuing in order to maintain a good reputation [1]. Subsequent research has constructed a number of proxy variables that characterize the degree of information asymmetry, such as enterprise age, asset size, issue size, underwriter reputation, etc., and found that information asymmetry will aggravate IPO underpricing. According to the above researches, this paper considers two specific forms of information asymmetry: the high-tech background of the enterprise and the impact of R \& D investment intensity on IPO underpricing.

First of all, foreign scholars have found that high-tech companies have higher IPO underpricing rates because they face more risks [2]. The same is true for China's start-up high-tech enterprises. In the course of their operations, capital flows often break and do not have a mature management system. They are easy to go bankrupt because of the changes in macroeconomic policies and the 
threats of external competitors. It is these risks and the uncertainty of the future value of the company that have caused investors to question and trigger the problem of adverse selection. It can be seen that the development of start-ups requires an independent and professional organization to regulate and assist them, and venture capital plays such a role. Explaining the IPO underpricing from the perspective of venture capital began in the 1990s. Megginson and Weiss proposed that the certification of venture capital can increase the value of enterprises and reduce information asymmetry, thus reducing the IPO underpricing rate. Then high-tech enterprises can consider using venture capital to reduce their own uncertainty, and send positive signals to the outside to ease the degree of underpricing [3]. Based on the above analysis, this paper proposes the following assumptions:

Hypothesis 1a: The IPO underpricing rate of high-tech enterprises is higher;

Hypothesis 1b: Participation of venture capital will weaken the positive correlation between high-tech background and IPO underpricing.

Aboody and Lev argue that R \& D investment is one of the sources of information asymmetry between investors and corporate management [4]. Guo et al. further suggest that $\mathrm{R} \& \mathrm{D}$ investment is the main cause of information asymmetry [5]. To sum up, there are several reasons: First, the information reflected in the R \& D expenditure data disclosed in the financial statements is limited. Insiders of the company have information on $\mathrm{R} \& \mathrm{D}$ projects, $\mathrm{R} \& \mathrm{D}$ processes, and research capabilities of employees, but the content and process of $\mathrm{R} \& \mathrm{D}$ are kept confidential for the sake of preventing competitors. It is difficult for public investors to judge the investment value of enterprises based on simple information, and most investors do not have such information gathering ability and professional knowledge, and it is easy to make adverse selection. Second, the enterprise $\mathrm{R} \& \mathrm{D}$ activities themselves are highly uncertain. The economic benefits brought by technological achievements will not be immediately reflected in the company's performance. The actual value of $\mathrm{R} \& \mathrm{D}$ investment is hard to be reflected in the IPO pricing process. Third, China's current accounting standards deal with the capitalization of $\mathrm{R} \& \mathrm{D}$ expenses, which gives the space for accounting policy selection, which will increase the difficulty that the actual income of R \& D fairly reflected to the stock price. Fourth, from a macro perspective, there is still a certain gap between the development level of China's stock market and developed countries. The intervention of government departments reduces the efficiency of IPO pricing, which will magnify information asymmetry due to the uncertainty and lag of R \& D income [6].

There has been some literature on the impact of $\mathrm{R} \& \mathrm{D}$ investment on IPO underpricing for more mature markets. On this basis, Cho et al. further discussed the moderator effect of venture capital on R \& D investment and IPO underpricing. According to the certification supervision hypothesis, venture capital can not only provide funds to start-ups, but also provide value-added services [7]. For example, technical advisory services belong to a value-added service. Venture capital can collect industry information for enterprises, assist in 
formulating technology development strategies, establish technology research and innovation cooperation alliances, and form continuous product development capabilities. This kind of service can reduce the probability of $\mathrm{R} \& \mathrm{D}$ failure, thus reducing the information asymmetry of the $\mathrm{R} \& \mathrm{D}$ activity itself. Venture capital will also supervise the process of information disclosure, improve the reliability of $\mathrm{R} \& \mathrm{D}$ expenditure data, and further reduce the degree of information asymmetry in $\mathrm{R} \& \mathrm{D}$ investment. However, for emerging markets, it is not excluded that venture capital has a short-term speculative tendency. This is because venture capital and start-ups also have information asymmetry. Venture capital may pay more attention to how to recover investment in a short period of time and obtain high profits. Therefore, it cannot provide effective value-added services, and may also package immature enterprises as soon as possible. In view of the rapid development and improvement of China's venture capital market under the influence of policy support and capital internationalization, this paper first makes assumptions from a positive perspective:

Hypothesis 2a: The higher the R \& D investment intensity, the more serious the IPO underpricing;

Hypothesis 2b: Participation of venture capital will weaken the positive correlation between $\mathrm{R} \& \mathrm{D}$ investment intensity and IPO underpricing.

As we all know, the development of high-tech enterprises is inseparable from the support of R \& D investment. Duysters and Hagedoorn proposed that R \& D investment is the source of high-tech enterprises to gain competitive advantage [8]. Compared with non-high-tech enterprises, investors generally give higher valuations to $\mathrm{R} \& \mathrm{D}$ activities of high-tech enterprises [9]. Then the conjecture is: Will high-tech enterprises with high $\mathrm{R} \& \mathrm{D}$ investment intensity show a lower IPO underpricing rate? In order to verify that companies with high-tech background and high $\mathrm{R} \& \mathrm{D}$ investment face less information asymmetry than enterprises with high-tech or high $\mathrm{R} \& \mathrm{D}$ investment, this paper uses future cash flow uncertainty as an agent for information asymmetry to measure the uncertainty of the cash flow of the sample company from 2009 to 2016. The uncertainty of cash flow is measured by the standard deviation of the annual cash recovery rate of all assets. Table 1 shows descriptive statistics classified by R \& D investment intensity and high-tech background.

It can be seen from Panel A in Table 1 that the cash flow uncertainty of high-tech enterprises (high $\mathrm{R} \& \mathrm{D}$ investment enterprises) is higher than that of non-high-tech enterprises (low R \& D investment enterprises), and the results also prove hypothesis $1 \mathrm{a}$ and hypothesis $2 \mathrm{a}$ are reasonable. However, panel $\mathrm{B}$ and panel $\mathrm{C}$ further indicate that the cash flow uncertainty of high-tech enterprises with high $\mathrm{R} \& \mathrm{D}$ investment intensity (mean $=0.0591$ ) is lower than that of high-tech enterprises with low $\mathrm{R} \& \mathrm{D}$ investment (mean $=0.1301)$, and is lower than non-high-tech enterprises with high $\mathrm{R} \& \mathrm{D}$ investment $($ mean $=$ 0.0781). Table 2 shows the regression results of high-tech enterprises, $R \& D$ investment intensity and cash flow uncertainty. Uncertainty of cash flows is the dependent variable; high-tech enterprises and $\mathrm{R} \& \mathrm{D}$ investment intensity are 
Table 1. Descriptive statistics on cash flow uncertainty. (a) Entire sample; (b) high-tech firms; (c) non-tech firms.

(a)

\begin{tabular}{cccccc}
\hline & $\mathrm{N}$ & Mean & $\mathrm{SD}$ & Minimum & Maximum \\
\hline High-tech firms $\mathrm{b}^{\mathrm{b}}$ & 288 & 0.0749 & 0.0362 & 0.0179 & 0.1996 \\
Non-tech firms & 61 & 0.0725 & 0.0378 & 0.0221 & 0.2191 \\
T-test of mean difference & & \multicolumn{5}{c}{$\mathrm{t}=4.46(\mathrm{p}<0.01)$} \\
High-R \& D firms ${ }^{\mathrm{a}}$ & 122 & 0.0835 & 0.0388 & 0.0179 & 0.2191 \\
Low-R \& D firms & 227 & 0.0696 & 0.0343 & 0.0202 & 0.1996 \\
T-test of mean difference & & \multicolumn{5}{c}{$\mathrm{t}=3.45(\mathrm{p}<0.01)$} \\
\hline
\end{tabular}

(b)

\begin{tabular}{cccccc}
\hline & $\mathrm{N}$ & Mean & $\mathrm{SD}$ & Minimum & Maximum \\
\hline High-R \& D firms & 118 & 0.0591 & 0.0371 & 0.0179 & 0.1909 \\
Low-R \& D firms & 170 & 0.1301 & 0.0349 & 0.0202 & 0.1996 \\
T-test of mean difference & \multicolumn{5}{c}{$\mathrm{t}=-2.76(\mathrm{p}<0.01)$} \\
\hline
\end{tabular}

(c)

\begin{tabular}{cccccc}
\hline & $\mathrm{N}$ & Mean & SD & Minimum & Maximum \\
\hline High-R \& D firms & 4 & 0.0781 & 0.0618 & 0.0736 & 0.2191 \\
Low-R \& D firms & 57 & 0.0683 & 0.0326 & 0.0221 & 0.1621 \\
T-test of mean difference & \multicolumn{5}{c}{$\mathrm{t}=5.02(\mathrm{p}<0.01)$} \\
\hline
\end{tabular}

${ }^{a}$ Enterprises with R \& D investment intensity higher than the median sample R \& D intensity in the year before listing are defined as high R \& D investment intensity enterprises; otherwise, they are defined as low $R \& D$ investment intensity enterprises. ${ }^{b}$ The definition of high-tech enterprises is based on the" Management Measures for the Recognition of High-tech Enterprises" issued by the Ministry of Science and Technology of China in 2008 and related documents.

Table 2. Regression results of high-tech enterprises, R \& D investment intensity and cash flow uncertainty.

\begin{tabular}{ccccc}
\hline Variables & \multicolumn{4}{c}{ Uncertainty of cash flows } \\
\hline $\mathrm{TECH}^{\mathrm{a}}$ & $0.0120^{* * *}$ & & $0.0029^{* * *}$ & $0.0041^{* * *}$ \\
& $\left(3.4761^{\mathrm{d}}\right)$ & & $(5.5040)$ & $(3.4029)$ \\
$\mathrm{R} \& \mathrm{D}^{\mathrm{b}}$ & & $0.1709^{* * *}$ & $0.1811^{* * *}$ & $0.3493^{*}$ \\
& & $(2.9397)$ & $(2.9404)$ & $(1.8928)$ \\
$\mathrm{TECH}^{*} \mathrm{R} \& \mathrm{D}^{\mathrm{c}}$ & & & & $-0.1893^{* * *}$ \\
& & & & $(-2.9670)$ \\
Intercept & $0.0725^{* * *}$ & $0.0656^{* * *}$ & $0.0673^{* * *}$ & $0.0624^{* * *}$ \\
Adj- $\mathrm{R}^{2}$ & $(15.5024)$ & $(18.2169)$ & $(13.5898)$ & $(8.8827)$ \\
Prob $>\mathrm{F}$ & 0.0820 & 0.0331 & 0.0870 & 0.1962 \\
Observations & 0.0001 & 0.0001 & 0.0001 & 0.0001 \\
\hline
\end{tabular}

${ }^{\mathrm{a}} \mathrm{TECH}$ is a dummy variable. For high-tech enterprises, TECH is 1, for non-high-tech enterprises, TECH is 0 . ${ }^{\mathrm{b}} \mathrm{R} \& \mathrm{D}$ is a dummy variable, and for high $\mathrm{R} \& \mathrm{D}$ investment enterprises, $\mathrm{R} \& \mathrm{D}$ is 1 , and vice versa. 'TECH * R \& D is the intersection of TECH and R \& D. ${ }^{d}$ The $t$ value is reported in parentheses, and "***”, “**”, and "*» indicate significant at the $1 \%, 5 \%$, and $10 \%$ levels, respectively. 
the independent variables. From this table, it can be found that the high-tech background $(t=5.5040)$ and the $\mathrm{R} \& \mathrm{D}$ investment intensity $(\mathrm{t}=2.9404)$ are significantly positively correlated with the cash flow uncertainty, but there is a significant negative correlation between the intersection of the two and the cash flow uncertainty $(t=-2.9670)$. The above results show that enterprises with both high-tech background and high R \& D investment intensity face lower cash flow uncertainty than enterprises with single characteristics, that is, information asymmetry. Therefore, the high-tech demand has a moderator effect on the relationship between R \& D investment intensity and IPO underpricing rate. At the same time, the R \& D investment intensity also has a moderator effect on the relationship between the high-tech background and the IPO underpricing rate, so the following assumptions are made:

Hypothesis 3a: The demand for technology can reduce the information asymmetry of R \& D investment. Therefore, the higher the R \& D investment intensity of high-tech enterprises, the lower the IPO underpricing rate;

Hypothesis 3b: R \& D investment can reduce the information asymmetry of technology, so for enterprises with high $\mathrm{R} \& \mathrm{D}$ investment intensity, the IPO underpricing rate of high-tech background is lower.

\section{Research Design}

\subsection{Modeling}

Referring to the practice of the existing literature, this paper constructs an econometric model with the adjusted IPO underpricing rate as the dependent variable, with venture capital holding, high-tech background, and R \& D investment intensity as independent variables. First, based on Hypotheses 1a and 2a, the following model is established to verify the impact of high-tech background and $\mathrm{R} \& \mathrm{D}$ investment intensity on IPO underpricing.

$$
M A R=\alpha_{0}+\alpha_{1} V C+\alpha_{2} T E C H+\alpha_{3} R D+\sum_{i=4}^{n} \alpha_{i} \text { Controls }+\varepsilon
$$

Next, in order to verify hypotheses $1 \mathrm{~b}$ and $2 \mathrm{~b}$, the model (1) is expanded to:

$$
\begin{aligned}
M A R= & \beta_{0}+\beta_{1} V C+\beta_{2} T E C H+\beta_{3} R D+\beta_{4} V C \times T E C H \\
& +\sum_{i=5}^{n} \beta_{i} \text { Controls }+v \\
M A R= & \gamma_{0}+\gamma_{1} V C+\gamma_{2} T E C H+\gamma_{3} R D+\gamma_{4} V C \times T E C H \\
& +\gamma_{5} V C \times R D+\sum_{i=6}^{n} \gamma_{i} \text { Controls }+\mu
\end{aligned}
$$

Finally, according to Hypothesis $3 \mathrm{a}$ and $3 \mathrm{~b}$, the following model is established to test the effect of the interaction effect between high-tech background and R \& $\mathrm{D}$ input intensity on the IPO underpricing rate. The specific variables are defined in Table 3.

$$
\begin{aligned}
M A R= & \lambda_{0}+\lambda_{1} V C+\lambda_{2} T E C H+\lambda_{3} R D+\lambda_{4} V C \times T E C H+\lambda_{5} V C \times R D \\
& +\lambda_{6} T E C H \times R D+\sum_{i=7}^{n} \lambda_{i} \text { Controls }+v
\end{aligned}
$$


Table 3. Definition of variables.

\begin{tabular}{|c|c|c|}
\hline $\begin{array}{l}\text { Variable } \\
\text { symbol }\end{array}$ & Variables & Definition \\
\hline \multicolumn{3}{|c|}{ Dependent variable } \\
\hline MAR & $\begin{array}{l}\text { Adjusted IPO } \\
\text { underpricing rate }\end{array}$ & $\begin{array}{c}\text { (closing price }- \text { issue price)/issue price }- \text { current } \\
\text { market rate of return }\end{array}$ \\
\hline \multicolumn{3}{|c|}{ Independent variable } \\
\hline $\mathrm{VC}$ & Venture capital & $\begin{array}{l}\text { Dummy variable; the company's IPO } \\
\text { has a VC holding of } 1 \text {, otherwise } 0 .\end{array}$ \\
\hline TECH & technology & $\begin{array}{l}\text { Dummy variable; the company was identified } \\
\text { as a high-tech firms indicating that the demand } \\
\text { for technology is high, recorded as } 1 \text {, otherwise } 0 .\end{array}$ \\
\hline $\mathrm{RD}$ & $\mathrm{R} \& \mathrm{D}$ input & $\begin{array}{l}\text { Ratio of R \& D expenditure to main } \\
\text { business income in the year before listing }\end{array}$ \\
\hline \multicolumn{3}{|c|}{ Control variable } \\
\hline Age & firm age & $\operatorname{Ln}($ listing date-establishment date) \\
\hline Delay & Listing interval & $\operatorname{Ln}$ (days between the listing date and the issue date) \\
\hline LEV & Financial risk & Asset-liability ratio for the year prior to listing \\
\hline LOTT & lottery & $\begin{array}{l}\text { Ratio of the number of shares issued and } \\
\text { the number of shares purchased }\end{array}$ \\
\hline ROE & Return on equity & Weighted return on equity in the year prior to listing \\
\hline Scale & Firm scale & $\operatorname{Ln}$ (Total assets at the end of the year prior to listing) \\
\hline Size & Financing scale & $\operatorname{Ln}($ scale $)$ \\
\hline TR & Turnover rate & Turnover rate on listing date \\
\hline UR & $\begin{array}{l}\text { Underwriter } \\
\text { reputation }\end{array}$ & $\begin{array}{l}\text { Dummy variable; IPO business of leading } \\
\text { underwriter is ranked top } 10 \text {, recorded as } 1 \text {, otherwise } 0\end{array}$ \\
\hline Year & Year of listing & $\begin{array}{l}\text { Control variable of the year; it is recorded } \\
\text { as } 1 \text { in the current year, otherwise } 0\end{array}$ \\
\hline IND & industry & $\begin{array}{l}\text { Control variable of the industry; it is recorded } \\
\text { as } 1 \text { of the industry, otherwise } 0\end{array}$ \\
\hline
\end{tabular}

\subsection{Sample and Data}

This paper adopts the companies listed on the GEM of China from October 30, 2009 to October 9, 2012, and eliminates some companies with missing data (only 5 samples), then finally obtains 349 samples. The reason for choosing this time period is that the IPO was suspended from September 2012 to January 2014. After 2014, the Shenzhen Stock Exchange imposed restrictions on the IPO first-day price increase and maintain the upper limit of the underpricing rate of $44 \%$. Under limited conditions, the results of the study will lose its meaning. Therefore, the sample time period of this article is more reasonable and does not affect the final results. The listed issuance data and financial data required for the research are sourced from the WIND database, and information such as venture capital holdings are manually collected from the prospectus disclosed by the companies. 
The following criteria are used to define whether a listed company has a venture capital background: if the name of the top 10 shareholders in the listing includes "venture capital", "start-up investment" and "innovative capital", it is defined as venture capital holdings, and if only includes "investment" or "capital", it is further identified by inquiring about their main business. According to this standard, there are 223 companies with a background of venture capital in the sample, accounting for $63.9 \%$. Regarding whether a listed company belongs to the high-tech industry, firstly we check whether it has the title of "high-tech enterprise" recognized by the state or local government, and then combine the "Management Measures for the Recognition of High-tech Enterprises" issued by the Ministry of Science and Technology in 2008 to make a judgement. A total of 288 companies with high-tech backgrounds accounted for $82.5 \%$ of the sample, mainly distributed in bio-pharmaceutical, electronic information, new materials and other industries. This shows that most of the companies listed on the GEM are technology-based enterprises, and the demand for technology is relatively high. Finally, unlike the previous practice of using the comprehensive ranking of investment banks to define reputation, this paper refers to the ranking of China's investment banks IPO business published by Bloomberg to judge whether the underwriters have reputation. Which is more reasonable.

\section{Empirical Methodologies and Results}

\subsection{Descriptive Statistics}

Table 4 presents descriptive statistics for the full sample and subsamples. From the column (1), the average first-day excess return rate of China's GEM market is as high as $34.9 \%$. Compared with the main board market in the same period, the IPO underpricing problem is more prominent. High-tech enterprises accounted for $82.5 \%$ of all enterprises, and enterprises with venture capital holdings accounted for $63.9 \%$, which is consistent with the positioning and characteristics of the GEM market. The average IPO success rate was low (mean = 1.2085 , median $=0.779)$, and the average first-day turnover rate was higher (mean $=0.7145$, median $=0.7617$ ), indicating that China's issuance market is highly active. In addition, $55.3 \%$ of underwriters have a high reputation.

It can be found from columns (2) - (7) that unlike some research focusing on mature markets, China's venture capital holding companies have higher IPO underpricing rates; venture capital tends to invest in high-tech enterprises, but $\mathrm{R}$ \& D investment intensity has not shown high, which indicates that the professionalism and maturity of China's venture capital are not enough. The underwriters selected by the issuer with venture capital help have a significantly higher reputation (mean $=0.6278$ ), which proves venture capital has certification effect and can attract more qualified institutions investors. Secondly, the independent sample T-test of high-tech enterprise groups and non-high-tech enterprise groups shows that high-tech enterprises have significantly higher IPO underpricing rates $(t=2.369)$, which is in line with the previous hypothesis 1a. In 
Table 4. Full sample and group descriptive statistics ${ }^{\mathrm{a}}$.

\begin{tabular}{|c|c|c|c|c|c|c|c|c|c|c|}
\hline & All (1) & $\mathrm{VC}(2)$ & Non-VC (3) & TECH (4) & Non-TECH (5) & High-R \& D (6) & low-R \& D (7) & (2)-(3) & (4)-(5) & (6)-(7) \\
\hline \multirow{2}{*}{ MAR } & 0.3499 & 0.3754 & 0.3050 & 0.3262 & 0.3123 & 0.3700 & 0.3663 & $0.0704^{*}$ & $0.0139^{* *}$ & 0.0040 \\
\hline & $(0.2600)$ & $(0.3593)$ & $(0.3245)$ & $(0.3585)$ & $(0.4148)$ & $(0.3600)$ & $(0.3779)$ & (1.7948) & $(2.3690)$ & (1.1348) \\
\hline \multirow{2}{*}{$\mathrm{VC}$} & 0.6389 & 1 & 0 & 0.6424 & 0.6230 & 0.6567 & 0.6300 & 1 & 0.0194 & 0.0257 \\
\hline & (1) & $(0)$ & (0) & $(0.4801)$ & $(0.4887)$ & $(0.4771)$ & $(0.4838)$ & - & $(0.2827)$ & $(0.4790)$ \\
\hline \multirow{2}{*}{ TECH } & 0.8252 & 0.8296 & 0.8175 & 1 & 0 & 0.9672 & 0.7489 & 0.0121 & 1 & $0.2183^{\star * *}$ \\
\hline & (1) & $(0.3768)$ & $(0.3878)$ & (0) & $(0)$ & $(0.1788)$ & $(0.4346)$ & $(0.2837)$ & - & $(6.6000)$ \\
\hline \multirow{2}{*}{$\mathrm{RD}$} & 0.0522 & 0.0519 & 0.0527 & 0.0572 & 0.0287 & 0.0860 & 0.0342 & -0.0007 & $0.0285^{\star * *}$ & $0.0517^{\star * *}$ \\
\hline & $(0.0400)$ & $(0.0329)$ & $(0.0340)$ & $(0.0326)$ & $(0.0253)$ & $(0.0330)$ & $(0.0133)$ & $(-0.1130)$ & $(7.6752)$ & $(16.8091)$ \\
\hline \multirow{2}{*}{ Age } & 2.2489 & 2.2430 & 2.2593 & 2.2497 & 2.2449 & 2.2307 & 2.2587 & -0.0163 & 0.0048 & -0.0279 \\
\hline & $(2.2700)$ & $(0.4699)$ & $(0.3136)$ & $(0.4339)$ & $(0.3492)$ & $(0.4392)$ & $(0.4094)$ & $(-0.3844)$ & $(0.0826)$ & $(-0.5812)$ \\
\hline \multirow{2}{*}{ Delay } & 2.4090 & 2.4166 & 2.3956 & 2.3982 & 2.4602 & 2.3614 & 2.4343 & 0.0211 & -0.0620 & $-0.0729^{*}$ \\
\hline & $(2.3000)$ & $(0.3498)$ & $(0.2859)$ & $(0.3291)$ & $(0.3200)$ & $(0.2900)$ & $(0.3450)$ & $(0.6105)$ & $(-1.3702)$ & $(-2.0931)$ \\
\hline \multirow{2}{*}{ LEV } & 0.3940 & 0.3838 & 0.4120 & 0.3856 & 0.4337 & 0.3214 & 0.4330 & $-0.0281^{\star}$ & $-0.0482^{\star *}$ & $-0.1120^{\star * *}$ \\
\hline & $(0.4029)$ & $(0.1439)$ & $(0.1499)$ & $(0.1473)$ & $(0.1374)$ & $(0.1376)$ & $(0.1362)$ & $(-1.7080)$ & $(-2.4557)$ & $(-7.2463)$ \\
\hline \multirow{2}{*}{ LOTT } & 1.2085 & 1.1985 & 1.2262 & 1.2660 & 0.9375 & 1.4369 & 1.0857 & -0.0283 & $0.3284^{* *}$ & $0.3512^{*}$ \\
\hline & $(0.7790)$ & $(1.2733)$ & $(1.8732)$ & $(1.6221)$ & $(0.7957)$ & $(2.0756)$ & $(1.0881)$ & $(-0.1475)$ & $(2.3506)$ & (1.7447) \\
\hline \multirow{2}{*}{$\mathrm{ROE}$} & 0.3571 & 0.3457 & 0.3761 & 0.3620 & 0.3333 & 0.3855 & 0.3411 & $-0.0304^{* *}$ & $0.0282^{\star}$ & $0.0444^{\star * *}$ \\
\hline & $(0.3232)$ & $(0.1396)$ & $(0.1240)$ & $(0.1388)$ & $(0.1118)$ & $(0.1437)$ & $(0.1274)$ & $(-2.1012)$ & $(1.7110)$ & $(2.8612)$ \\
\hline \multirow{2}{*}{ Scale } & 2.9693 & 2.9707 & 2.9668 & 2.9677 & 2.9770 & 2.9588 & 2.9747 & 0.0041 & $-0.0093^{* *}$ & $-0.0158^{* * *}$ \\
\hline & $(2.9700)$ & $(0.0305)$ & $(0.0313)$ & $(0.0310)$ & $(0.0288)$ & $(0.0303)$ & $(0.0300)$ & $(1.1332)$ & $(-2.2482)$ & $(-4.6788)$ \\
\hline \multirow{2}{*}{ Size } & 3.0020 & 3.0019 & 3.0023 & 3.0047 & 3.0035 & 3.0034 & 3.0013 & 0.0010 & 0.0013 & 0.0021 \\
\hline & (2.9994) & $(0.0266)$ & $(0.0274)$ & $(0.0267)$ & $(0.0276)$ & $(0.0263)$ & $(0.0272)$ & $(-0.1187)$ & $(0.4447)$ & $(0.7061)$ \\
\hline \multirow{2}{*}{ TR } & 0.7145 & 0.7159 & 0.7118 & 0.7012 & 0.7772 & 0.6902 & 0.7275 & 0.0041 & $-0.0760^{\star * *}$ & $-0.0373^{\star}$ \\
\hline & $(0.7617)$ & $(0.1883)$ & $(0.1849)$ & $(0.1937)$ & $(0.1351)$ & $(0.2037)$ & $(0.1762)$ & $(0.1967)$ & $(-3.6675)$ & $(-1.7080)$ \\
\hline \multirow{2}{*}{ UR } & 0.5530 & 0.6278 & 0.4206 & 0.5417 & 0.6070 & 0.5655 & 0.5463 & $0.2072^{\star * *}$ & -0.0649 & 0.0193 \\
\hline & (1) & $(0.4845)$ & $(0.4956)$ & $(0.4991)$ & $(0.4926)$ & $(0.4977)$ & $(0.4990)$ & $(3.7810)$ & $(-0.9325)$ & $(0.3454)$ \\
\hline Observations & 349 & 223 & 126 & 288 & 61 & 122 & 227 & - & - & - \\
\hline
\end{tabular}

${ }^{a}$ Column (1) reports the average of each variable in the whole sample, and the median is shown in parentheses; the (2) - (7) column is descriptive Statistics based on whether there is VC holding, whether it is a high-tech enterprise, or the intensity of R \& D investment, the average of each variable is reported, and the standard deviation is shown in parentheses; the last three columns report the mean difference between the groups under different divisions. Due to space limitations, this paper does not report complete full-sample descriptive statistics.

addition, high-tech enterprises also have higher R \& D investment intensity, lower leverage rate, higher winning rate and lower first-day turnover rate. The reason why the market activity is not as high as expected may be the uncertainty of enterprises is stronger, and investors will maintain a wait-and-see attitude in order to avoid risks. Finally, it can be found that enterprises with high $\mathrm{R} \& \mathrm{D}$ investment intensity show a high IPO underpricing rate, but the results are not significant and need to be further tested; this type of enterprise also shows a higher ROE ratio $(t=2.8612)$, indicating that $\mathrm{R} \& \mathrm{D}$ activities are an important way for enterprise innovation, which will affect the profitability of enterprises in the long run. 


\subsection{Analysis of Regression Results}

Regression results of Hypothesis 1 - 3 can be seen in Table 5. The first column is the regression of all control variables against the IPO underpricing rate. It can be

Table 5. Regression results of hypothesis $1-3$.

\begin{tabular}{|c|c|c|c|c|c|}
\hline Variables & & & MAR & & \\
\hline $\mathrm{VC}$ & & $\begin{array}{l}0.0650^{\star \star} \\
(2.1000)\end{array}$ & $\begin{array}{l}0.1310^{*} \\
(1.8393)\end{array}$ & $\begin{array}{c}0.0611 \\
(0.8043)\end{array}$ & $\begin{array}{c}0.0759 \\
(0.9896)\end{array}$ \\
\hline TECH & & $\begin{array}{c}0.0516^{\star * *} \\
(3.2798)\end{array}$ & $\begin{array}{c}0.0240^{\star * *} \\
(4.0302)\end{array}$ & $\begin{array}{c}0.0341^{\star * *} \\
(4.5322)\end{array}$ & $\begin{array}{c}0.1009^{* * *} \\
(4.2467)\end{array}$ \\
\hline $\mathrm{RD}$ & & $\begin{array}{c}0.1077^{\star * *} \\
(3.0154)\end{array}$ & $\begin{array}{c}0.2703^{* * *} \\
(4.0208)\end{array}$ & $\begin{array}{l}0.4114^{*} \\
(1.8908)\end{array}$ & $\begin{array}{l}0.3989^{* *} \\
(2.2598)\end{array}$ \\
\hline $\mathrm{VC} * \mathrm{TECH}$ & & & $\begin{array}{c}-0.1203 \\
(-1.0296)\end{array}$ & $\begin{array}{l}-0.1425^{\star} \\
(-1.7522)\end{array}$ & $\begin{array}{l}-0.1486^{*} \\
(-1.8262)\end{array}$ \\
\hline $\mathrm{VC}^{\star} \mathrm{RD}$ & & & & $\begin{array}{l}2.3306^{\star *} \\
(2.4966)\end{array}$ & $\begin{array}{l}2.1832^{\star *} \\
(2.3257)\end{array}$ \\
\hline $\mathrm{TECH}{ }^{*} \mathrm{RD}$ & & & & & $\begin{array}{l}-1.9815^{*} \\
(-1.7484)\end{array}$ \\
\hline Age & $\begin{array}{c}-0.0290 \\
(-0.8211)\end{array}$ & $\begin{array}{c}-0.0246 \\
(-0.7001)\end{array}$ & $\begin{array}{c}-0.0253 \\
(-0.7213)\end{array}$ & $\begin{array}{c}-0.0211 \\
(-0.6043)\end{array}$ & $\begin{array}{c}-0.0223 \\
(-0.6408)\end{array}$ \\
\hline Delay & $\begin{array}{c}0.2864^{\star * *} \\
(6.2711)\end{array}$ & $\begin{array}{c}0.2785^{\star * *} \\
(6.1025)\end{array}$ & $\begin{array}{c}0.2759^{* * *} \\
(6.0371)\end{array}$ & $\begin{array}{l}0.2820^{* * *} \\
(6.2084)\end{array}$ & $\begin{array}{c}0.2788^{\star * *} \\
(6.1364)\end{array}$ \\
\hline LEV & $\begin{array}{l}-0.2246^{*} \\
(-1.8510)\end{array}$ & $\begin{array}{c}-0.1934 \\
(-1.5352)\end{array}$ & $\begin{array}{c}-0.1940 \\
(-1.5398)\end{array}$ & $\begin{array}{c}-0.1614 \\
(-1.2844)\end{array}$ & $\begin{array}{c}-0.1713 \\
(-1.3625)\end{array}$ \\
\hline LOTT & $\begin{array}{l}-0.0238^{* *} \\
(-2.3165)\end{array}$ & $\begin{array}{l}-0.0234^{* *} \\
(-2.2717)\end{array}$ & $\begin{array}{l}-0.0236^{* *} \\
(-2.2912)\end{array}$ & $\begin{array}{l}-0.0235^{\star *} \\
(-2.3041)\end{array}$ & $\begin{array}{l}-0.0232^{* *} \\
(-2.2727)\end{array}$ \\
\hline ROE & $\begin{array}{l}-0.1867^{\star} \\
(-1.6678)\end{array}$ & $\begin{array}{c}-0.1621 \\
(-1.3279)\end{array}$ & $\begin{array}{c}-0.1561 \\
(-1.2775)\end{array}$ & $\begin{array}{c}-0.1734 \\
(-1.4274)\end{array}$ & $\begin{array}{c}-0.1740 \\
(-1.4347)\end{array}$ \\
\hline Scale & $\begin{array}{c}-0.5755 \\
(-0.7952)\end{array}$ & $\begin{array}{c}-0.8527 \\
(-1.1575)\end{array}$ & $\begin{array}{c}-0.8851 \\
(-1.2004)\end{array}$ & $\begin{array}{c}-1.0263 \\
(-1.3986)\end{array}$ & $\begin{array}{c}-1.1124 \\
(-1.5121)\end{array}$ \\
\hline Size & $\begin{array}{c}-0.6029 \\
(-0.8312)\end{array}$ & $\begin{array}{c}-0.5165 \\
(-0.7095)\end{array}$ & $\begin{array}{c}-0.4935 \\
(-0.6776)\end{array}$ & $\begin{array}{c}-0.4468 \\
(-0.6179)\end{array}$ & $\begin{array}{c}-0.3164 \\
(-0.4343)\end{array}$ \\
\hline TR & $\begin{array}{l}1.0557^{\star * *} \\
(12.4540)\end{array}$ & $\begin{array}{l}1.0259^{* * *} \\
(11.9099)\end{array}$ & $\begin{array}{l}1.0229^{* * *} \\
(11.8726)\end{array}$ & $\begin{array}{l}1.0255^{\star * *} \\
(11.9954)\end{array}$ & $\begin{array}{l}1.0261^{\star * *} \\
(12.0160)\end{array}$ \\
\hline UR & $\begin{array}{c}-0.0436 \\
(-1.4754)\end{array}$ & $\begin{array}{l}-0.0593^{* *} \\
(-1.9665)\end{array}$ & $\begin{array}{l}-0.0577^{*} \\
(-1.9115)\end{array}$ & $\begin{array}{l}-0.0587^{\star *} \\
(-1.9616)\end{array}$ & $\begin{array}{l}-0.0610^{* *} \\
(-2.0376)\end{array}$ \\
\hline Year & control & control & control & control & control \\
\hline IND & control & control & control & control & control \\
\hline Intercept & $\begin{array}{c}2.6966 \\
(1.3230)\end{array}$ & $\begin{array}{c}3.2810 \\
(1.5970)\end{array}$ & $\begin{array}{c}3.2746 \\
(1.5936)\end{array}$ & $\begin{array}{l}3.5651^{*} \\
(1.7457)\end{array}$ & $\begin{array}{l}3.3873^{*} \\
(1.6572)\end{array}$ \\
\hline Adj- $R^{2}$ & 0.4862 & 0.4906 & 0.4907 & 0.4986 & 0.5000 \\
\hline F-statistic & 37.5861 & 28.9335 & 26.7942 & 25.7142 & 24.1799 \\
\hline Observations & 349 & 349 & 349 & 349 & 349 \\
\hline
\end{tabular}


seen that the longer the time before listing, the objective conditions may change during this period, resulting in information asymmetry and IPO underpricing. The winning rate was significantly negatively correlated with the IPO underpricing rate $(\mathrm{t}=-2.3165)$. The first day turnover rate was significantly positively correlated with the IPO underpricing rate $(t=12.454)$. These two market indicators indicate the higher the investor mood, the higher the underpricing rate, and the high underpricing rate in China's stock market is largely caused by the high closing price in the secondary market. Companies that are sponsored by high-reputation underwriters exhibit lower underpricing rates, as such underwriters tend to have better valuation pricing techniques and are more professional and accountable in the inquiry process. In addition, age, leverage, ROE ratio, firm size and issue size are negatively correlated with IPO underpricing. After controlling the year and industry factors, the above conclusions are consistent with the research of many scholars such as Li Xiwen (2013), Zhang Xueyong and Liao Li (2011).

The second column is the regression result after adding the independent variable. At the $5 \%$ level, venture capital has a significant positive correlation with the IPO underpricing rate, indicating that China's venture capital have not fully played the role of certification, or in order to chase reputation at the cost of increasing the underpricing rate; the high-tech and $\mathrm{R} \& \mathrm{D}$ investment are significantly positively correlated with the IPO underpricing rate at the $1 \%$ level, respectively. Hypothesis 1a and Hypothesis $2 \mathrm{a}$ are proved, that is, high-tech enterprises or enterprises with higher R \& D investment intensity have higher IPO underpricing rates. The two hypotheses also ensures the rationality and effectiveness of the subsequent analysis of the moderator effects of venture capital.

\subsubsection{The Moderator Effect of Venture Capital on the Relationship between High Technology and IPO Underpricing}

The third column of Table 5 reports the regression results of model (2), that is, whether the venture capital has a weakening effect on the positive correlation between high-tech and IPO underpricing. It can be found that the sign of the coefficient of venture capital and high-tech intersection $(\mathrm{VC} * \mathrm{TECH})$ is negative, and the fourth column and the fifth column also get the same result, and it is significant at the $10 \%$ level, which indicates that the venture capital does have negative moderator effect. Although this paper previously found that China's venture capital institutions did not fully play the role of certification, it could not be completely denied. In recent years, under the influence of capital internationalization and national policy support, the domestic venture capital market has developed rapidly. Specifically, the "certification effect" reflects the impact of the information on venture capital holdings, and the "supervision effect" reflects the impact of venture capital participation in the company's operation and management. Even if venture capital cannot perform due diligence in the process of providing value-added services, it is still professional and cautious in screening the invested companies. After all, this is related to the recovery of funds and the 
realization of profits. Therefore, its shareholding information is sufficient to show that the invested high-tech enterprises have growth potential and expected value. This positive signal allows investors to rationally and objectively view the risk characteristics of high-tech enterprises and give relatively reasonable valuation, which eventually alleviate the IPO underpricing.

\subsubsection{The Moderator Effect of Venture Capital on the Relationship between R \& D Investment and IPO Underpricing}

The fourth column of Table 5 reports the regression results of model (3), that is, whether the venture capital has a weakening effect on the positive correlation between $\mathrm{R} \& \mathrm{D}$ investment intensity and IPO underpricing rate. The results show that the sign of the coefficient of venture capital and R \& D input (VC * $\mathrm{RD}$ ) is positive and significant at the $5 \%$ level, assuming that $2 \mathrm{~b}$ does not hold. But this indirectly confirms another conjecture proposed in this paper: China's venture capital has a short-term speculative tendency. In particular, some young venture capital institutions are eager to put immature enterprises on the market in order to establish their own reputation as soon as possible. They not only fail to play a supervisory role in the company's $\mathrm{R} \& \mathrm{D}$ process, but also may participate in the manipulation of the disclosure of $\mathrm{R} \& \mathrm{D}$ information. Therefore, the involvement of venture capital actually exacerbates the information asymmetry of $\mathrm{R} \& \mathrm{D}$ investment, which in turn increases the IPO underpricing rate. In order to further prove that venture capital is directly involved in the $\mathrm{R} \& \mathrm{D}$ decision of enterprises, this paper regresses the two sub-samples of venture capital holdings and non-venture holdings respectively. The specific results are shown in Table 6. In the regression of venture capital holdings, the R \& D input intensity is significantly positively correlated with the underpricing rate at the $1 \%$ level $(t=2.6123)$; in the regression of non-venture capital holdings, the R \& D input intensity is significantly positively correlated with the underpricing rate at the $5 \%$ level $(t=2.209)$. The results show that venture capital does have the potential to directly interfere with the company's $\mathrm{R} \& \mathrm{D}$ decisions, and strengthens the positive correlation between $\mathrm{R} \& \mathrm{D}$ investment intensity and IPO underpricing.

\subsubsection{The Effect of the Cross-Effect of High-Tech and R \& D Investment on IPO Underpricing}

The last column of Table 5 reports the regression results for model (4). Both the high-tech background $(\mathrm{t}=4.2467)$ and the $\mathrm{R} \& \mathrm{D}$ input intensity $(\mathrm{t}=2.2598)$ are significantly positively correlated with the underpricing rate, while the intersection of the two $\left(\mathrm{TECH}^{*} \mathrm{RD}\right)$ is negatively correlated to underpricing rate at the $10 \%$ significance level, which indicates that there is a negative moderator effect between high-tech and R \& D investment, so hypothesis 3a and hypothesis $3 \mathrm{~b}$ are proved. R \& D activities lead to information asymmetry between investors and invested companies, but investors often value $\mathrm{R} \& \mathrm{D}$ activities high for companies with high technology needs. Similarly, the need for technology also leads information asymmetry between investors and enterprises, and $\mathrm{R} \& \mathrm{D}$ 
Table 6. Regression results of high-tech, R \& D investment intensity and IPO underpricing rate.

\begin{tabular}{|c|c|c|}
\hline \multirow{2}{*}{ Variables } & \multicolumn{2}{|c|}{ MAR } \\
\hline & $\mathrm{VC}$ & Non-VC \\
\hline \multirow{2}{*}{ TECH } & -0.0120 & 0.1250 \\
\hline & $(-0.1601)$ & $(1.1362)$ \\
\hline \multirow{2}{*}{$\mathrm{RD}$} & $4.2542^{\star * *}$ & $2.7571^{\star *}$ \\
\hline & $(2.6123)$ & $(2.2090)$ \\
\hline \multirow{2}{*}{$\mathrm{TECH} * \mathrm{RD}$} & $-3.6301^{\star *}$ & -3.4030 \\
\hline & $(-2.0434)$ & $(-1.6179)$ \\
\hline \multirow{2}{*}{ Age } & -0.0260 & 0.0201 \\
\hline & $(-0.6472)$ & $(0.2799)$ \\
\hline \multirow{2}{*}{ Delay } & $0.3151^{\star * *}$ & $0.1790^{* *}$ \\
\hline & $(5.6653)$ & $(2.2481)$ \\
\hline \multirow{2}{*}{ LEV } & -0.0951 & -0.2230 \\
\hline & $(-0.5681)$ & $(-1.1433)$ \\
\hline \multirow{2}{*}{ LOTT } & $-0.0260^{*}$ & $-0.0154^{*}$ \\
\hline & $(-1.7819)$ & $(-1.6690)$ \\
\hline \multirow{2}{*}{ ROE } & -0.2151 & -0.0537 \\
\hline & $(-1.3134)$ & $(-0.2658)$ \\
\hline \multirow{2}{*}{ Size } & -0.0550 & -1.2813 \\
\hline & $(-0.0614)$ & $(-1.0265)$ \\
\hline \multirow{2}{*}{ Scale } & -1.0070 & -1.5651 \\
\hline & $(-1.0791)$ & $(-1.2678)$ \\
\hline \multirow{2}{*}{ TR } & $1.0734^{\star \star \star}$ & $0.8333^{\star * *}$ \\
\hline & $(9.6242)$ & $(5.9851)$ \\
\hline \multirow{2}{*}{ UR } & $-0.0781^{\star \star}$ & -0.0300 \\
\hline & $(-1.9790)$ & $(-0.6621)$ \\
\hline Year & control & control \\
\hline IND & control & control \\
\hline \multirow{2}{*}{ Intercept } & 2.1961 & $8.0708^{\star *}$ \\
\hline & $(0.8170)$ & $(2.4791)$ \\
\hline Adj- $R^{2}$ & 0.5472 & 0.4529 \\
\hline $\mathrm{F}$-statistic & 21.1112 & 9.6062 \\
\hline Observations & 223 & 126 \\
\hline
\end{tabular}

activities ensure the future growth of enterprises. Therefore, high-tech enterprises with high R \& D investment intensity can be favored by investors. It can be seen that for enterprises with high-tech background, the coefficient of $\mathrm{R} \& \mathrm{D}$ 
input intensity $(\mathrm{RD})$ becomes $-1.5826(0.3989-1.9815=-1.5826)$, which indicates that the information asymmetry accompanying $\mathrm{R} \& \mathrm{D}$ activities is not enough to improve underpricing rate of high-tech enterprises.

Based on the above analysis, this paper finds that venture capital directly regulates the relationship between high-tech background, R \& D investment intensity and IPO underpricing rate. The difference is that in the process of screening and investing in enterprises, venture capital can play a certification role, thereby reducing the IPO underpricing rate of high-tech enterprises. However, in the process of participating in operation, it is not guaranteed to supervise the R \& D activities of enterprises well, nor can it improve the disclosure quality of the R \& $\mathrm{D}$ information, which in turn will intensify the information asymmetry between the investors and the invested enterprises, resulting in the high underpricing rate. In addition, companies with high-tech background and high $\mathrm{R} \& \mathrm{D}$ investment intensity show lower IPO underpricing rates, and this feature will be more significant in the case of venture capital holdings.

\subsection{Robustness Test}

Since the empirical model adds the intersection of three independent variables, there may be multiple collinearity problems. In order to avoid the estimation error, this paper re-evaluates the moderator effect of venture capital with reference to the residual centralization method proposed by Lance (1988) [10]. Firstly, build the following model (see Table 7 for regression results):

$$
\begin{gathered}
V C \times T E C H=\varphi_{0}+\varphi_{1} V C+\varphi_{2} T E C H+R V C T \\
V C \times R D=\varsigma_{0}+\varsigma_{1} V C+\varsigma_{2} R D+R V C R \\
T E C H \times R D=\vartheta_{0}+\vartheta_{1} T E C H+\vartheta_{2} R D+R T E R
\end{gathered}
$$

The residuals of regressions (5), (6), and (7) are obtained by formula transformation, $\widehat{R V C T}, \widehat{R V C R}, \widehat{R T E R}$ are substituted for the intersection terms in models (2), (3), and (4). From the regression results reported in Table 8, the

Table 7. Regression results of independent variables and their intersections.

\begin{tabular}{cccc}
\hline Variables & $\mathrm{VC}{ }^{*} \mathrm{TECH}$ & $\mathrm{VC}{ }^{*} \mathrm{RD}$ & $\mathrm{TECH}^{*} \mathrm{RD}$ \\
\hline $\mathrm{VC}$ & $0.8221^{* * *}$ & $0.0521^{* * *}$ & - \\
& $(39.9720)$ & $(29.1151)$ & $0.0321^{\star * *}$ \\
$\mathrm{TECH}$ & $0.6265^{* * *}$ & - & $(21.5501)$ \\
& $(24.0862)$ & & $0.8893^{* * *}$ \\
$\mathrm{RD}$ & - & $0.6242^{* * *}$ & $(52.5310)$ \\
& & $(23.9510)$ & $-0.0251^{* * *}$ \\
Intercept & $-0.5121^{* * *}$ & $-0.0333^{* * *}$ & $(-18.7544)$ \\
Adj-R & $(-19.0551)$ & $(-16.5328)$ & 0.9285 \\
Prob $>\mathrm{F}$ & 0.8643 & 0.8019 & 0.0001 \\
$\mathrm{~N}$ & 0.0001 & 0.0001 & 349 \\
\hline
\end{tabular}


Table 8. Regression of the residual of intersection terms and the IPO underpricing rate (residual centralization method).

\begin{tabular}{|c|c|c|c|c|c|c|}
\hline \multirow{2}{*}{ Variables } & \multicolumn{6}{|c|}{ MAR } \\
\hline & Coeff. ( $t$ value) & VIF & Coeff. ( $t$ value) & VIF & Coeff. ( $t$ value) & VIF \\
\hline $\mathrm{VC}$ & $\begin{array}{l}0.0650^{* *} \\
(2.1000)\end{array}$ & 1.093 & $\begin{array}{l}0.0661^{* *} \\
(2.1561)\end{array}$ & 1.093 & $\begin{array}{l}0.0680^{* *} \\
(2.2230)\end{array}$ & 1.096 \\
\hline TECH & $\begin{array}{l}0.0330^{* * *} \\
(3.2122)\end{array}$ & 1.163 & $\begin{array}{l}0.0341^{* * *} \\
(3.4382)\end{array}$ & 1.164 & $\begin{array}{l}0.0372^{\star * *} \\
(3.1776)\end{array}$ & 1.164 \\
\hline $\mathrm{RD}$ & $\begin{array}{l}0.2703^{* * *} \\
(4.0208)\end{array}$ & 1.343 & $\begin{array}{l}0.4114^{*} \\
(1.8809)\end{array}$ & 1.346 & $\begin{array}{l}0.3989^{* *} \\
(2.2598)\end{array}$ & 1.351 \\
\hline$\widehat{R V C T}$ & $\begin{array}{c}-0.1203 \\
(-1.0296)\end{array}$ & 1.018 & $\begin{array}{l}-0.1425^{*} \\
(-1.7522)\end{array}$ & 1.123 & $\begin{array}{l}-0.1486^{\star} \\
(-1.8262)\end{array}$ & 1.126 \\
\hline$\widehat{R V C R}$ & - & - & $\begin{array}{l}2.3310^{* *} \\
(2.4966)\end{array}$ & 1.134 & $\begin{array}{l}2.1832^{\star *} \\
(2.3257)\end{array}$ & 1.149 \\
\hline$\widehat{R T E R}$ & - & - & - & - & $\begin{array}{l}-1.9815^{*} \\
(-1.7484)\end{array}$ & 1.062 \\
\hline Age & $\begin{array}{c}-0.0253 \\
(-0.7213)\end{array}$ & 1.074 & $\begin{array}{l}-0.0211 \\
(-0.6043)\end{array}$ & 1.077 & $\begin{array}{c}-0.0223 \\
(-0.6408)\end{array}$ & 1.077 \\
\hline Delay & $\begin{array}{l}0.2759^{\star * *} \\
(6.0371)\end{array}$ & 1.109 & $\begin{array}{l}0.2820^{\star * *} \\
(6.2084)\end{array}$ & 1.113 & $\begin{array}{l}0.2788^{\star * *} \\
(6.1364)\end{array}$ & 1.116 \\
\hline LEV & $\begin{array}{c}-0.1940 \\
(-1.5398)\end{array}$ & 1.683 & $\begin{array}{c}-0.1614 \\
(-1.2844)\end{array}$ & 1.701 & $\begin{array}{c}-0.1713 \\
(-1.3625)\end{array}$ & 1.707 \\
\hline LOTT & $\begin{array}{l}-0.0236^{\star *} \\
(-2.2912)\end{array}$ & 1.202 & $\begin{array}{l}-0.0235^{\star *} \\
(-2.3041)\end{array}$ & 1.202 & $\begin{array}{l}-0.0232^{\star *} \\
(-2.2727)\end{array}$ & 1.203 \\
\hline ROE & $\begin{array}{c}-0.1561 \\
(-1.2775)\end{array}$ & 1.340 & $\begin{array}{c}-0.1734 \\
(-1.4274)\end{array}$ & 1.345 & $\begin{array}{c}-0.1740 \\
(-1.4347)\end{array}$ & 1.345 \\
\hline Scale & $\begin{array}{c}-0.8851 \\
(-1.2004)\end{array}$ & 2.552 & $\begin{array}{l}-1.0263 \\
(-1.3989)\end{array}$ & 2.567 & $\begin{array}{c}-1.1124 \\
(-1.5121)\end{array}$ & 2.586 \\
\hline Size & $\begin{array}{l}-0.4935 \\
(-0.6776)\end{array}$ & 1.889 & $\begin{array}{c}-0.4468 \\
(-0.6179)\end{array}$ & 1.891 & $\begin{array}{c}-0.3164 \\
(-0.4343)\end{array}$ & 1.925 \\
\hline TR & $\begin{array}{l}1.0229^{* * *} \\
(11.8726)\end{array}$ & 1.279 & $\begin{array}{l}1.0255^{\star * *} \\
(11.9954)\end{array}$ & 1.280 & $\begin{array}{l}1.0261^{\star \star \star} \\
(12.0160)\end{array}$ & 1.280 \\
\hline UR & $\begin{array}{l}-0.0577^{\star} \\
(-1.9115)\end{array}$ & 1.115 & $\begin{array}{l}-0.0587^{\star *} \\
(-1.9616)\end{array}$ & 1.115 & $\begin{array}{l}-0.0610^{\star *} \\
(-2.0376)\end{array}$ & 1.119 \\
\hline Intercept & $\begin{array}{c}3.3161 \\
(1.6130)\end{array}$ & & $\begin{array}{l}3.5614^{\star} \\
(1.7443)\end{array}$ & & $\begin{array}{l}3.4424^{*} \\
(1.6867)\end{array}$ & \\
\hline Year & control & & control & & control & \\
\hline IND & control & & control & & control & \\
\hline Adj- $R^{2}$ & 0.4911 & & 0.4990 & & 0.5000 & \\
\hline F-statistic & 26.7942 & & 25.7143 & & 24.1800 & \\
\hline Observations & 349 & & 349 & & 349 & \\
\hline
\end{tabular}


coefficients of RVCT in columns 3 and 5 are significantly negative $(t=-1.7522$, -1.8262 ), thereby hypotheses $1 b$ holds. Secondly, RVCR is significantly positive at the $5 \%$ level, indicating that venture capital has a direct positive moderator effect on the positive correlation between $\mathrm{R} \& \mathrm{D}$ investment intensity and IPO underpricing rate. Finally, RTER has a negative correlation with the underpricing rate at the $10 \%$ significance level, indicating that the demand for high technology can weaken the information asymmetry of $\mathrm{R} \& \mathrm{D}$ expenditure, and $\mathrm{R} \&$ $\mathrm{D}$ activities can also reduce the high underpricing rate of high-tech enterprises. Therefore, hypotheses $3 \mathrm{a}$ and $3 \mathrm{~b}$ are still valid. All of the variance inflation factors (VIF) in Table 8 are greater than 0 and less than 3 , indicating that there is no multicollinearity problem. The regression results using the residual centering method are consistent with the previous conclusions. This paper also carried out the Glazer test and drawing test on the measurement model. It was found that there were no serious heteroscedasticity and autocorrelation problems. In addition, the paper uses the average of the ratio of $\mathrm{R} \& \mathrm{D}$ expenditure to main business income in 3 years prior to the listing as the R \& D investment intensity, and the results are still robust. Due to limited space, it will not be listed here.

The empirical model in this paper is quite simple, consisting mainly of dummy variables and control variables. All parameters can be well estimated and are consistent with economics common sense. With the gradual improvement of variables, $\mathrm{R}^{2}$ gradually increases, and the random error term satisfies the white noise. In summary, this model does not have significant setting errors.

$$
\begin{gathered}
\widehat{R V C T}=V C \times T E C H-\left(\widehat{\varphi_{0}}+\widehat{\varphi_{1}} V C+\widehat{\varphi_{2} T E C H}\right) \\
\widehat{R V C R}=V C \times R D-\left(\widehat{\varsigma_{0}}+\widehat{\varsigma_{1}} V C+\widehat{\varsigma_{2}} R D\right) \\
\widehat{R T E R}=T E C H \times R D-\left(\widehat{\vartheta_{0}}+\widehat{\vartheta_{1}} T E C H+\widehat{\vartheta_{2}} R D\right)
\end{gathered}
$$

\section{Conclusions}

This paper has the following findings: Firstly, consistent with the information asymmetry theory, due to the high risk of high-tech enterprises, investors need more information and expertise to evaluate this type of enterprise. Potential adverse selection problems tend to lead to bias in valuation, which intensifies IPO underpricing. In addition, $\mathrm{R} \& \mathrm{D}$ activities and disclosure processes are characterized by information asymmetry, and enterprises with higher R \& D investment intensity significantly showed a higher IPO underpricing rate. Secondly, venture capital has weakened the positive correlation between high-tech background and IPO underpricing rate, which indicates that China's venture capital has certain certification effect. As a professional investment institution, venture capital has a good ability to screen enterprises and projects. Its shareholding information sends a positive signal to external investors, indicating that the invested company has investment value or growth potential, which has prompted the market to make more rational judgments. However, in the context of the 
current transition economy, venture capital also has a tendency to speculate. In order to speed up the establishment of reputation and recover funds, venture capital will be eager to push the immature enterprises into the market; in the management of the invested enterprises, it has the motive to use self-professional knowledge and accounting policy choices to whitewash the report, and R \& D expenditures are just the object that is easier to manipulate. Therefore, the participation of venture capital further strengthens the positive correlation between R \& D investment intensity and IPO underpricing rate. Third, the cross-effect of high-tech background and R \& D investment intensity can reduce the high IPO underpricing rate caused by the information asymmetry of the other party. In other words, high-tech enterprises with high R \& D investment intensity will show a lower IPO underpricing rate. After considering the multicollinearity problem, the conclusions are still robust.

According to the conclusions of this study, some inspiration can be obtained. First of all, technology and R \& D activities are all factors that generate information asymmetry. These two are accompanied by each other and affect each other. When solving the IPO underpricing problem, we must combine them for consideration. The previous literature has only been studied from the perspective of $\mathrm{R} \& \mathrm{D}$ investment. This paper considers the high-tech factors to supplement the existing achievements. Second, we must improve the quality of R \& D investment information disclosure. Because the GEM market is unique, its disclosure standards should also be differentiated from the main board market, reflecting its high-risk, high-tech, and high-growth characteristics. In addition to the disclosure of general financial data, specific content should be made on the R \& D content, input, process, etc., and the R \& D progress should be updated regularly after listing. Third, venture capital institutions should strengthen their own management, focus on long-term interests, give full play to the role of certification and supervision, and use their professional knowledge to help the invested companies grow and develop. This also helps venture capital to truly build a high reputation in the industry. Finally, in the process of IPO pricing, in addition to issuers, investors, and intermediaries to do their part and try to ease the information asymmetry between them, the regulatory authorities must continue to promote the market-oriented reform of China's issue pricing mechanism, continuously improve the efficiency of IPO pricing.

\section{Conflicts of Interest}

The author declares no conflicts of interest regarding the publication of this paper.

\section{References}

[1] Beatty, R.P. and Ritter, J.R. (1986) Investment Banking, Reputation, and the Underpricing of Initial Public Offerings. Journal of Financial Economics, 15, 1-2. https://doi.org/10.1016/0304-405X(86)90055-3

[2] Lowry, M. and Schwert, G.W. (2002) IPO Market Cycles: Bubbles or Sequential 
Learning? Journal of Finance, 57, 3. https://doi.org/10.1111/1540-6261.00458

[3] Megginson, W.L. and Weiss, K.A. (1991) Venture Capitalist Certification in Initial Public Offerings. Journal of Finance, 46, 3.

https://doi.org/10.1111/j.1540-6261.1991.tb03770.x

[4] Aboody, D. and Lev, B. (2000) Information Asymmetry, R \& D, and Insider Gains. Journal of Finance, 55, 6. https://doi.org/10.1111/0022-1082.00305

[5] Maria, C.A. and Balatbat (2006) Discussion of Explaining the Short-and Long-Term IPO Anomalies in the US by R \& D. Journal of Business Finance \& Accounting, 33, 3-4.

[6] Hu, Z.Y. and Li, J. (2015) R \& D Investment and IPO Underpricing: The Moderator Effect of Venture Capital. Nankai Management Review, 18, 113-124.

[7] Cho, J. and Lee, J. (2013) The Venture Capital Certification Role in R \& D: Evidence From IPO Underpricing In Korea. Pacific Basin Finance Journal, 23, 156-164. https://doi.org/10.1016/j.pacfin.2013.01.005

[8] Duysters, G. and Hagedoorn, J. (2000) Core Competences and Company Performance in the World-Wide Computer Industry. Journal of High Technology Management Research, 11, 16-27. https://doi.org/10.1016/S1047-8310(00)00022-5

[9] Zantout, Z.Z. and Tsetsekos, G.P. (1994) The Wealth Effects of Announcements of R \& D Expenditure Increases. Journal of Financial Research, 17, 26-34.

https://doi.org/10.1111/j.1475-6803.1994.tb00186.x

[10] Lance, C.E. (1988) Residual Centering, Exploratory and Confirmatory Moderator Analysis, and Decomposition of Effects in Path Models Containing Interactions. Applied Psychological Measurement, 12, 163-175.

https://doi.org/10.1177/014662168801200205 